\title{
LINGUAGEM E REALIDADE: UMA ANÁLISE DO CRÁTILO DE PLATÃO
}

Jorge Ferro Piqué*

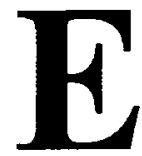

ste artigo visa esclarecer a concepf̧ão da linguagem, particularmente do nome, que Platão apresenta em seu diálogo Crátilo. Esse diálogo, tão fundamental para a história do pensamento lingüístico ocidental, talvez seja uma das obras de Platão que mais $\propto$ casionou comentários posteriores, especialmente nesta segunda metade do século XX (Robinson, 1955; Lorenz e Mittelstrass, 1967; Bollack, 1972; Genette, 1972; Froidefond, 1982; Goldshmidt, 1982; Duran, 1983; Kahn, 1986; Neves, 1987; Vandelvelde, 1987).

Entretanto, julgamos que uma de suas características mais importantes, ou seja, seu estilo paródico, talvez ainda não tenha sido suficientemente explicitada. Essa característica estilística, por sua vez, tem profundas implicações para a correta leitura do texto e a clara compreensão do pensamento lingüístico platônico antes do diálogo $O$ Sofista. Sem essa clareza, o texto pode levar, como de fato levou, a interpretações diferentes c até mesmo contraditórias de seu conteúdo.

Pode-se estabelecer, no Crátilo, uma primeira análise, em duas partes, de acordo com o interlocutor de Sócrates. São dois: Hermógenes, um discípulo seu, e Crátilo, pensador de vertente heraclitiana. O primeiro participa com Sócrates na maior parte do diálogo (Crat., 383a-427d) e o segundo apenas no

* Universidade Federal do Paraná (e-mail: jorge@humanas.ufpr.br.) 
quarto final (Crat., 427d-440e). É possivel também subdividir a parte inicial em três seções.

Primeiramente temos uma introdução (Crat., 383a-384e) onde Hermógenes expōe a Sócrates resumidamente as posiçōes que se confrontam quanto à questão do fundamento da linguagem. Em resumo, para Crátilo "cada coisa tem por natureza um nome apropriado, e que não se trata da denominação que alguns homens convencionaram dar-lhes" (Crat., 383a), o que está de acordo com a teoria naturalista dos nomes, segundo a qual as palavras têm sentido certo e sempre o mesmo. Para Hermógenes, ao contrário, os nomes das coisas são estabelecidos por convenção humana. Essa questão tomou em geral o nome de controvérsia physis-nomos ou physis-thesis.

Colocado diante dessas duas posições, Sócrates aceita examiná-las. Começa primeiramente pela tese admitida por Hermógenes e a parte $384 \mathrm{e}-387 \mathrm{~d}$ do diálogo será a sua crítica, uma vez que a sua conseqüência mais imediata seria a total impossibilidade de conhecimento através da linguagem, devido ao seu caráter completamente arbitrário, dando nesse caso razão aos sofistas, para os quais basta falar para dizer a "verdade".

Sócrates procura reduzir essa arbitrariedade, primeiramente ressaltando o caráter coletivo da convenção, que se opõe ao particular subjetivo. Em seguida, já que Hermógenes, como seu discípulo fiel, aceita que a relação entre Linguagem e Mundo possa ser verdadeira ou falsa, e que, portanto, os nomes, enquanto partes de proposições verdadeiras, devem ser necessariamente verdadeiros, limita a convenção a convencionar o verdadeiro. Esta conclusão favorece o afastamento de Sócrates, na obra, de posições sofísticas.

Finalmente, como Hermógenes ainda resiste, Sócrates critica a tese de Protágoras da não-existência nas próprias coisas de uma essência de algum modo permanente, sendo a verdade, o real, a opinião de cada um segundo as coisas the pareçam. Para Protágoras não há essência, só aparência, não há verdade absoluta, todo o conhecimento é pessoal e particular. Refuta também a tese de Eutidemo, segundo a qual "as coisas são semelhantes e sempre para todo o mundo" (Crat., 386a).

Para Sócrates "as coisas devem ser em si mesmas de essência permanente, não estão em relação conosco, nem na nossa dependência, nem podem ser deslocadas em todos os sentidos por nossa fantasia, porém existem por si mesmas, de acordo com sua essência natural" (Crat., 386d-e).

Assim, o Mundo, sejam os objetos, sejam as ações, tem uma organização permanente. A diferença necessária entre o bom e o mau, o judicioso e o insensato, a razão e a sem-razão, diferença esta herdada por Platão do socratismo puro, implica nisso.

Da mesma forma que a natureza de um corte depende da natureza do objeto cortante e da natureza do objeto cortado, o dizer humano deve procurar 
recortar o Mundo segundo a natureza desse mesmo Mundo. Toda técnica humana, techne, se apóia na physis e age conforme sua própria natureza.

Exemplificando: se uma tesoura corta uma folha de papel, é porque a folha é "cortável", isso faz parte de sua natureza. O Mundo também, "se é recortado" pela linguagem, o é devido a sua natureza, da qual faz parte ser recortável assim, ou dizendo o mesmo de outro modo, “conjuntizável” assim, já que o que existe é uma única operação: separar-rcunir. Mas isso não significa que o seja de qualquer maneira. $O$ Mundo não admite qualquer sentido.

Neste século, as análises semânticas de linguas de povos indígenas, com concepções radicalmente diferentes das categorias curopéias tradicionais, favoreceram a noção de um certo relativismo de base lingüistica, para o qual não haveria um Mundo, mas sim vários, tantos quantas fossem as estruturas lingüísticas existentes. $O$ exemplo da diversidade de organização do campo semântico das cores foi repetido várias vezes como um paradigma incontestável. De fato, temos línguas em que o que nós discernimos pelos nomes de amarelo e verde, são representados por apenas um nome. Ou, ao contrário, o que nós chamamos de $a z u l$, seja claro ou escuro, para certas linguas tem dois nomes diferentes e não são encaradas como sendo a mesma cor. Mas o que é esquecido nesses casos é que se são apresentadas várias organizações possíveis é porque há um substrato físico que as permite, mas não a todas as organizaçōes ou recortes. Assim, por exemplo, não há línguas que agrupem sob um mesmo nome o branco c o preto. É o continuum físico, real, do espectro luminoso, que orienta a diversidade de possibilidades de se dar nomes às cores.

Para Platão, da mesma forma, essa ordem fundamental do Mundo impõe um limite à arbitrariedade da linguagem. Essa arbitrariedade só se manifesta no que chamariamos hoje de significante do signo lingüistico. $O$ onoma, geralmente traduzido por nome em Platão, antes do diálogo $O$ Sofista, é instrumento para informar a respeito das coisas e para separá-las de acordo com sua natureza, pois só enquanto de alguma forma ligada ao Mundo, a linguagem, sendo uma techne, poderá operar sobre cle.

Quem tem o conhecimento para julgar a adequação dos nomes criados é o dialético, que os usa para interrogar e responder. A justeza (orthotes) do instrumento só patentear-se-á no contato com o Mundo, para o qual e a partir do qual foi feito. Esse o motivo de Platão criticar a teoria convencionalista na sua versão mais radical, pois dessa forma estaria excluída, por sua total arbitrariedade, qualquer utilização filosófica da linguagem. "Privarmo-nos disso”, isto é, do discurso, "com efeito, seria desde logo - perda suprema - privar-nos da filosofia” (Sof., 260a).

Na terceira parte do diálogo Crátilo (387d-427a), Hermógenes apresenta uma certa resistência à crítica de Sócrates e pede uma demonstração da natural exatidão dos nomes. Sócrates corrige essa formulação dizendo que os nomes 
não são exatos, mas que têm uma "certa" correção (physei te tina orthoteta echon - Crat., 391a-b).

Assim, concluindo que há algo de certo no que Crátilo diz, ou seja, que "os nomes das coisas derivam da sua natureza" e que "nem todo homem é demiurgo de nomes", pergunta-se que orthotes, que justeza é esta, a dos nomes.

Paradoxalmente, o que Sócrates irá demonstrar nessa parte central do diálogo, pela aplicação da posição de Crátilo a aproximadamente 140 nomes, é que o método etimológico é apenas uma engenhosidade humana, com um caráter muitas vezes derrisório. $O$ que mais propriamente faz é parodiar o método etimológico, expondo suas falhas e levantando conexões com doutrinas filosóficas certamente criticáveis para Platão. Essa exposição clara do método, levandoo até o seu fundamento que é, como veremos a imitação da essência das coisas por meio de sons e sílabas, assumida pelo próprio Sócrates, e que ocupa uma grande parte do diálogo, é fundamental para problematizar o naturalismo lingüístico. Ao que parece, Crátilo, assim como Heráclito, é um tanto obscuro na expressão (bem no início do diálogo, Hermógenes pedira a Sócrates para “interpretar o oráculo de Crátilo"). Sem essa "exposição", esse "desvelamento" dỏ procedimento etimológico, não seria possivel criticá-lo de uma maneira completa.

Assim, Sócrates começa mandando Hermógenes procurar um sofista para aprender com ele a exatidão dos nomes, mas como seu discípulo não tem dinheiro para pagar as aulas, indica-lhe o exame de Homero, como se este fosse uma espécie de "sofista dos pobres". Nos poemas homéricos distinguem-se nomes dados por deuses e dados por homens, como no caso do rio Xanto-Escamandro, ou diferentes nomes dados ao mesmo referente, como por exemplo Astianax-Escamandrio para o filho de Heitor. Nesse exame etimológico, Sócrates propõe o princípio diretor de que é certo dar o mesmo nome ao pai e ao filho.

Novo sinal de que durante essa parte do diálogo as coisas não são como parecem, o que não impediu alguns comentaristas da obra de tomarem a sério as palavras de Platão, é o pequeno aviso que Sócrates dá a Hermógenes e indiretamente o autor desse diálogo dá aos seus leitores: "Mas, acautela-te, para que eu não faça alguma tramóia contigo". Ao dizer isto, e neste contexto, de que o gerador e o gerado devem ter o mesmo nome, Sócrates brinca com o nome de Hermógenes, o qual logo no início do diálogo confessou-se intrigado porque Crátilo lhe havia dito que, conforme a sua teoria, os nomes Sócrates e Crátilo, que por sinal têm em comum a palavra kratos (poder, força), eram naturais, mas o de Hermógenes não. Como Crátilo guardasse para si o sentido irônico dessa afirmação, Hermógenes pede a ajuda de Sócrates, que diz tratar-se de uma brincadeira de Crátilo, "talvez com isso queira insinuar que desejarias ser rico, porém nunca chegas a adquirir fortuna, por não ser de fato filho de Hermes", 
como seu nome sugeriria e muda de assunto. O sentido, no entanto, parece ser outro. De fato, Hermes é por excelência o "fornecedor de bens", mas outra característica sua é ser, como o chama Mircea Eliade, ${ }^{1}$ um trickster, isto é, um trapaceiro, um velhaco, caracterizado por sua astúcia. É nesse sentido que Hermógenes não é Hermógenes pois é, ao contrário, ingênuo. Será, entretanto, o próprio Sócrates que assumirá temporariamente esse parentesco com Hermes. Hermógenes terá um papel útil, a partir daqui, no diálogo, que visa sobretudo Crátilo - diríamos um "inocente útil" no confronto agônico entre duas "forças". Útil porque acompanhará e concordará com Sócrates em qualquer ponto, fazendo o movimento dialético fluir, mesmo sendo previamente avisado de que será desviado do caminho correto.

Platão enfatiza o caráter excepcional dessa incursão etimológica. Hermógenes será finalmente útil no final do diálogo, como exemplo vivo e presente de que o método etimológico é falho. É através do próprio ser do seu interlocutor, scja sua docilidade, seja sua insubmissão, seja o seu próprio nome, que Sócrates conduz o método dialético.

Essa tramóia de Sócrates, assumindo aqui uma postura que critica, não é simples, não se dá pela simples dicção do falso no lugar do verdadeiro. Há, na verdade, uma mescla. Por entre as 140 etimologias, encontram-se críticas a Heráclito, cuja doutrina Platão aprendeu do próprio Crátilo na juventude. Mas, mesmo no caráter falho desse método, alguma verdade se manifesta. Assim, desde a primeira etimologia que associa theoi (deuses) a thein (correr), é o mobilismo heraclitiano que entra em cena. Esse mobilismo não é negado por Platão de uma forma total, já que em $O$ Sofist $a$ o movimento é considerado como um dos gêneros fundamentais, mas juntamente com o repouso. Caso contrário, nenhum conhecimento verdadeiro seria possivel, já que o Mundo seria apenas um fluxo permanente, onde nenhum objeto estabilizar-se-ia o suficiente para ser conhecido ou mesmo denominado.

O que Platão evidencia nessas etimologias é a incongruência do método, já que um mesmo onoma pode, por natureza, nos levar à idéia do movimento e do repouso (como a palavra episteme, por exemplo), sendo que para Platão esses dois gêneros podem estar em comunhão com os seres, mas não entre si, pois isto significaria o aniquilamento de ambos. Já para Heráclito, ao contrário, justamente o fato de episteme levar tanto ao repouso como ao movimento seria uma evidência de que os nomes existem "por natureza", pois manisfestar-se-ia nesse nome o princípio da unidade dos opostos. ${ }^{2}$

'ELIADE, M. História das crenças e das idéias religiosas. Tomo I: Da Idade da Pedra aos mistérios de Elêusis. Vol. 2: Dos vedas a Dioniso. Rio de Janeiro: Zahar, 1978, p. 108.

${ }^{2}$ Cf. o fragmento 48: "Do arco o nome é vida e a obra é morte". In: Pré-socráticos. São Paulo: Abril Cultural, 1978, p. 84. 
Voltando ao texto: Sócrates começa a aplicar o princípio de que cada ser deve receber o nome do gênero a que pertence para que seja correto, justo. Sendo assim, começa a escalar uma linha genealógica ascendente, evidentemente patrilinear, que vai de filho a pai, de heróis a deuses, apresentando o sentido etimológico de cada nome próprio:

Orestes = caráter feroz e selvagem, asperczas das montanhas
Agamêmnon = admirável em persistência
Atreu = obstinado, intemerato, funesto
Pélops = só vê o que se encontra próximo
Tântalo = o mais infeliz dos homens
Zeus = causa da vida
Cronos = pureż, limpidez de entendimento
Urano = que olha para cima

Hermógenes mostra-se admirado por essa ascenção ao mundo divino que o método proporciona. Sócrates diz ser um conhecimento que caiu sobre ele não se sabe de onde, como uma espécie de inspiração, provavelmente influência da conversa pela manhã com o advinho Eutífron. Diz ele: “É bem possível que seu entusiasmo não somente me tivesse deixado os ouvidos cheios com sua sabedoria, como também apodcrou-se de minha alma" - e em seguida: "aproveitemos neste resto de dia essa influência para concluirmos o que falta dizer sobre os nomes".

Essa referência a Eutífron só pode ser interpretada como pura ironia socrática, já que no diálogo homónimo ele é apresentado como um fanático religioso que considerava ser piedoso acusar o próprio pai do assassinato de um escravo, escravo este que era assassino por sua vez, sem contar o fato de o pai de Eutífron tê-lo matado por descuido. A aproximação do método etimológico com a inspiração divinatória evidencia a falsa postura de Sócrates e o caráter insuficiente da teoria naturalista dos nomes. Quanto à influência de Eutífron, ela será transitória, como podemos observar logo em seguida: "mas amanhã, caso estejas de acordo, expulsemo-la por meio de esconjuros e purifiquemo-nos, se por ventura encontrarmos alguém que entenda de purificação, quer seja sacerdote ou sofista".

Como os nomes de heróis e de homens em geral propiciam o engano, a investigação recairá sobre nomes relacionados com as coisas eternas (aei onta) c a natureza. Assim dada, a explicação etimológica é prolifera e ao mesmo tempo decepcionante. Muitos nomes são explicados pelo recurso ao sensivel. Assim theoi, de thein, "por ter observado que todos eles se movem perpetuamente em seu curso". Aqui os deuses (theoi) são associados aos astros que percorrem 
(thein) o céu. Outros têm quatro significados possíveis, como o nome do deus A polo, e outros ainda são mesmo humorísticos, como selene (lua), que derivaria de selaenoneoaeia, termo forjado ao que parece por Platão, composto de selas (luz), neos (nova), enos (precedente) e aei (sempre). Hermógenes chega a dizer que the soa este nome como um ditirambo, tipo de verso que é usado algumas vezes em invectivas cômicas. E quando não é mais possível lançar mão de nenhuma cxplicação melhor, utiliza-se o expediente de que é uma expressão bárbara.

Note-se que esta primeira etapa do método, que procura uma definiçāo no onoma ("tal nome, Zeus, vale por um logos" - Crat., 396a), só é possível devido ao caráter tipológico sintético do grego, no qual os morfemas componentes, em alguns casos, são facilmente identificáveis. ${ }^{3}$

Todas essas derivações são entremeadas com repetidas expressões de ironia por parte de Sócrates, como estas: "há bastante probalilidade, se não tomar cuidado, de hoje mesmo vir a ficar mais sábio do que seria razoável”, “descobri, meu caro, um colmeal de sabedoria", "como são excelentes os cavalos de Eutífron" (que o conduzem pelo método etimológico), "penso que me adiantei bastante no terreno da sabedoria", "vesti a pele do leão" (como o herói Héracles, que também tinha traços cômicos). Todas essas expressóes devem nos acautelar sobre a firmeza da defesa que Platão faz do método etimológico que trata de expor.

Como já dissemos antes, a maior parte das etimologias é explicada por termos de movimento e suas nuances. Contra esse mobilismo de fundo heraclitiano, Platão se coloca claramente na seguinte passagem, onde diz em uma bela comparação, com forte ironia:

(...) parece (...) que os homens de antigamente quando estabeleceram os nomes, se encontravam em situação idêntica a da maioria dos sábios do nosso tempo, os quais, à força de andar à roda para investigar a natureza das coisas, acabam tomados de vertigem, acreditando que são as próprias coisas que giram e que tudo o mais ao redor deles é pelo mesmo teor. Não atribuem a culpa dessa maneira de pensar ao que se passa em seu íntimo, mas imaginam que decorre das próprias coisas, que nada é estável e permanente, e que tudo passa e se movimenta, e se encontra em permanente estado de modificação e geração. (Crat., $411 \mathrm{~b}-\mathrm{c})$

\footnotetext{
${ }^{3}$ Há no entanto linguas de tipo analitico, como o victnamita, onde todo vocábulo apresenta apenas um componente. Ao menos por esse motivo, nunca haveria um Crátilo vietnamita, isto $\dot{e}$, que procurasse expressōes definitórias dentro de um nome.
} 
Desse modo, uma série de termos do vocabulário do conhecimento encontra também uma origem etimológica no movimento. $O$ mais curioso dentre esses talvez seja noesis, a prestigiada ação intelectual, que Platão "explica" etimologicamente por neou hesis, ou seja, nada mais nada menos que desejo de novidade.

Mas o verdadeiro limite da investigação etimológica encontra-se nos nomes primitivos, já que não são compostos de outras palavras e, portanto, nem explicáveis por nenhum outro nome. ${ }^{4}$ Para estudar o seu exato significado, deve-se empregar algum método novo, no qual os nomes primitivos serão a mimesis vocal da coisa imitada. A partir desse momento, o nome não será visto mais como instrumento natural, mas como imagem, mais ou menos imperfeita, de um eidos, de uma Forma. E Platão lança mão de novas comparações: "do mesmo modo que o pintor reproduziu uma figura por meio da pintura, aqui também, criaremos a linguagem por meio da arte do nome ou do falar".

Todo o problema reside agora em verificar se as palavras primitivas foram formadas como convém, pois se elas são o fundamento das derivadas, toda a investigação poderá ficar comprometida com um erro aqui, como ficará patenteado mais tarde. Ao final dessa parte, Sócrates parece retornar a si mesmo e acaba por dizer: “Afiguram-se sobremodo impertinentes e ridiculas as reflexões que tenho formulado acerca dos nomes primitivos" (Crat., 426b).

A quarta e última parte do Crátilo (427d-440e) começa com Sócrates não se responsabilizando por nada que dissera, enquanto que Crátilo parece ter se deliciado com tantas etimologias em certa medida fantasiosas.

Desse modo Platão fará aqui uma critica explícita da teoria naturalista, a partir de uma revisão geral de tudo o que foi dito, pois "não há nada pior do que enganar alguém a si próprio" (Crat., 428d). São, portanto, retomadas as teses da teoria naturalista para melhor refutá-las. São elas:

1) “a correta aplicação dos nomes consiste em mostrar como é constituída a coisa".

Tanto a criação dos nomes primitivos como a dos derivados implica em erros de julgamento, o que introduz a falsidade entre as palavras. Como os nomes não são uma reprodução exata, uma verdadeira duplicação, mas a sua natureza é a de apresentar semelhanças parciais e modificáveis, já que a representação não deixa de ser representação, por acréscimo ou subtração, pois o que ela representa é um typos, um conjunto de traços fundamentais, há uma necessidade de encontrar-se um critério de verdade para as imagens ou representações que podem ser ou falsas ou verdadeiras. Não como dizia Hermógenes, nem falsas nem verdadeiras e também não como em Crátilo, para o qual eram sempre verdadeiras.

\footnotetext{
${ }^{4}$ Somente aqui iniciaria o trabalho do nosso imaginário "Crátilo vietnamita".
} 
Assim, para Platão, um objeto scria bem nomeado se todos os traços essenciais estivessem presentes no onoma. Como nos nomes ocorrem também letras dessemelhantes, que transmitem outro sentido, a comunicação só ć possível desde que haja também um certo grau de convenção, já que por ela a representação se firma tanto no semelhante quanto no dessemelhante. A convenção é um expediente inevitável, que completa a relação parcialmente natural com a coisa nomeada.

2) "a enunciação dos nomes tem por finalidade a instrução sendo seu único método verdadeiro".

Isso, para Platão, não poderia ser de forma alguma vendadeiro, primeiro porque, como vimos, os nomes podem ter embutidos em si um elemento convencional arbitrário; em segundo lugar, porque se houve um erro inicial na denominação, todo o desenvolvimento posterior ficará comprometido; e, em terceiro, se é afirmado que só é possivel conhecer as coisas pelos nomes, como os primciros "fazedores de nomes" conheceram as coisas, uma vez que os nomes primitivos não tinham ainda sido fixados? Uma possível explicação sobre-humana, divina, é rapidamente descartada.

Neste diálogo, Platão considera suficiente chegar-se à conclusão de que não é por meio de seus nomes que devemos procurar conhecer ou estudar as coisas, mas, de preferência, por meio delas mesmas. O conhecimento direto do auto, da própria coisa, é anterior e superior a seus nomes.

No entanto, essa conclusão não exclui, de forma total, por si só, qualquer utilização dialética da linguagem. No final de sua vida, na Carta VII, distingue Platão três elementos intermediários entre este auto tão fundamental e o seu conhecimento, a episteme, que reside na alma, a psyche. São eles o onoma, o logos e o eidolon, ou seja: o nome, a definição e a imagem.

Se é inegável que os elementos mais importantes são o objeto real c conhecível (to auto) e o conhecimento psíquico (he episteme) e que nome, definição $\mathrm{e}$ imagem apresentam variabilidade $\mathrm{e}$ contradiçāo, é sem dúvida por meio do penoso contato com esses elementos auxiliares, em certas condiçōes favoráveis, que pode o filósofo alçar-se até o inteligivel. A imperfeição dos onomata, enquanto participantes da natureza da mimesis, não permite o seu desvinculamento da questão da verdade, como defende a tese convencionalista, e nem o scu vínculo necessário com o eidos, a Forma, enquanto instrumento de uma techne (técnica) justa, que o identifica plenamente com a physis e o torna o único método verdadeiro de conhecimento, segundo a tese naturalista.

Concluindo, a posição de Platão nessa controvérsia contrapōe-se, assim, a uma oscilação entre dois extremos que as teorias gregas da linguagem manifestam: ou uma extrema confiança em que o nome diz a verdade (Heráclito e as primeiras tragédias), ou uma extrema desconfiança, em que os nomes são 
nada mais do que nomes (Parmênides, Demócrito e sofistas), identificando linguagem, opinião e verdade.

Para Platão, o discurso é de "natureza híbrida, verdadeira e falsa ao mesmo tempo" (Crat., 408c) como Pan, não por acaso filho de Hermes: ${ }^{5}$ “o que nele há de verdadeiro é macio e divino e reside no alto com os deuses, por outro lado, o que há de falso mora em baixo, com a multidão dos homens". Na visão platônica da palavra, na sua função de representação do inteligivel, mesmo que um tanto degradada, as duas teses contrárias convergem e são superadas, tendo ambas algo do verdadeiro eidos do onoma.

Desse modo, a linguagem, enquanto instrumento, tem o seu papel no aprimoramento do intelecto e é um meio na busca do conhecimento da essência, nesse ir c vir entre onoma, logos, eidolon e to auto, mas devido a sua imperfeição enquanto imitação é ao mesmo tempo um obstáculo à intuição pura das Formas Eternas pela alma imortal, que não admitiria nenhuma mediação.

Em geral as interpretações dos historiadores da Lingüística sobre o Crátilo apresentam uma abordagem ingênua em relação ao texto. Sem dar ouvidos aos avisos que Platão tantas vezes, como vimos acima, coloca na boca de Sócrates, levam a sério seu longo exercício etimológico, que nada mais é do que a desmontagem desse método, e concluem que o autor ao final não toma qualquer partido na controvérsia physis-nomos. ${ }^{6}$

Discordamos, portanto, que cste diálogo em particular tenha um caráter aporético como os primeiros, de simples negação de teses opostas, demonstrando simplesmente a sua imperfeição. Há algo positivo sendo enunciado: os nomes são simultaneamente por natureza e por convenção. Sendo os nomes, nessa fase do pensamento lingüístico de Platão, a essência do dizer, da linguagem, esse é o pressuposto necessário implicado pelo dogma platônico de que o conhecimento humano é possível e de que a linguagem tem propriedades que permitem ao mesmo tempo a enunciação do verdadeiro e do falso.

\section{RESUMO}

O artigo procura explicitar o uso paródico que Platão faz do método ctimológico de Crátilo. Como consequêencia, a posição platônica não se resume a uma simples negação aporística das teses naturalista e convencionalista, mas sim que ambas revelam aspectos

${ }^{5}$ Note-se nessa passagem o curioso jogo de palavras que Platão utiliza, pois sendo a palavra como Pan, filho de Hermes, ela é que é verdadeiramente "hermógenes".

6 "As duas posições são discutidas pelos participantes do diálogo, que não chegam, contudo, a uma conclusão definitiva”. In: ROBINS, R.H. Pequena história da lingiústica. Rio de Janeiro: Ao Livro Técnico, 1979, p. 14. 
essenciais da linguagem humana, aspectos estes que tornam possivel o conhecimento e a enunciação da verdade.

Palavras-chave: Platão, filosofia da linguagem, história da Lingüistica.

\section{ABSTRACT}

We intend to show Plato's Cratilo is parodic use of the etimological method. In consequence the platonic position about language is more complex than usually we think.

\section{REFERÊNCIAS BIBLIOGRÁFICAS}

BOLLACK, J. "Lén-deçà infini. Láporie du Cratyle". In: Poétique, n. 11, 1972, p. 309-14.

DURAN, A. "Concepto Platónico del Signo". In: Revista española de linguistica, año 18 , fasc. 1, 1983, p. 129-48.

ELIADE, M. História das crenças e das idéias religiosas. Tomo I: Da idade da pedra aos mistérios de Elêusis. Vol. 2: Dos Vedas a Dioniso. Rio de Janeiro: Zahar, 1978.

FROIDEFOND, Chr. "Linéarité, verticalité, rectitude: remarques sur l'órtholès platonicienne". In: Les étude philosophique, n. 3, 1982, p. 257-79.

GENETTE, G. "Avatars du cratylism". In: Poétique, n. 11, 1972, p. 367-94.

"L'éponymie du nom ou le cratylism du Cratyle". In: Critique, n. 307, dec., 1972, p. 1019-10.

GOLDSHMIDT, V. Essay sur le Cratyle: contribuition a l'histoire de la pensée de Platon. Paris: Vrin, 1982.

KAHN, Ch. H. "Les mots e les formes dans le Cratyle de Platon". In: JOLY, H. (Org.) Philosophie du langage et grammaire dans l'antiquité. Bruxelles: OUSIA, 1986, p. 91-103.

LORENZ, K.; MITTELSTRASS, J. "On rational philosophy of language: the programme in Plato's Cratylus reconsidered". In: Mind, vol. LXXVI, n. 301, jan. 1967, p. 489-516.

NEVES, Maria Helena de Moura. A vertente grega da gramática tradicional. Sāo Paulo: Hucitec/Univ. de Brasília, 1987.

PLATÃO, Cratyle. Texte établi et traduit par L. Méridier. 3. ed. Paris: Les Belles Lettres, 1950.

. Crátylo o del lenguaje. Trad., notas e introd. por V. Bécares Botas. Salamanca:

Ediciones Universidad de Salamanca, 1982. . Lettres. Texte établi et traduit par A. Diès. 5. ed. Paris: Les Belles Lettres, 1969. 
Le sophiste.Texte établi et traduit par J. Suilhé. 3. ed. Paris: Les Belles Lettres, 1969.

PRE-SOCRÁTICOS. S. Paulo: Abril Cultural, 1978.

ROBINS, R. H. Pequena história da lingüistica. Rio de Janeiro: Ao Livro Técnico. 1979. ROBINSON, R. "The theory of names in Plato's Cratylus". In: Revue internationale de philosophie (Études platoniciennes), n. 32, 1955, p. 221-36.

VANDELVELDE, P. "Le statut de l'étymologie dans le Cratyle de Platon". In: Les étude classique, t. LV, n. 2, 1987, p. 137-50. 